(4) A. Hansgirg.-Vol. ii., Prague, 1892, p. 207.

(5) G. Lagerhaim.- Sopra alcune Alghe d' acqua dolce nuove o rimarchevoli. Notarisia iii., fasc. 12, p. 592.

(6) A. Bonzi.-Intorno allo sirluppo sessuale di alcune Feoficee inferiori. Atti del congresso botanico internazionale di Genova, 1892, pp. 454-462. Tav, xvii.

(7) A. Hansgirix.-Grundzïge der Algenflora von Nieder-Oesterreich, Beitr. z. bot. Centralblatt, 1905, xviii., Abt. ii. Heft 3, p. 433.

(8) A. Scherfyel.--Phæocystis globosa nov. spec. nebst einigen Betrachtungen iiber die Phylogenie niederer insbesondere brauner Organisnen. Wissenschaftl. Meeresuntersuchungen, Abt. Helgoland, N.F. iv., 1900. $1^{\text {tes }}$ Heft.

(9) A. Scherffel.-Kleiner Beitrag zur Phylogenie einiger Gruppen niederer Organismen. Botan. Zeitung, 1901, 59, pp. 143-158.

(10) F. Oltmanns.-Morphologie und Biologie der Algen, vol. i., 1904 ; vol. ii., 1905.

(11) De Tont.-Sylloge Algarum, vol. iii. (Fucoidex). Patavii, 1895, p. 120.

(12) N. Wille. - Fngler and Prantl's Natiirliche Pflanzenfamilien, I. Teil, ii. Abt, p. 96. Leipzig, 1897.

(13) THomés Kryptogamen Flora von Deutschland, etc., bearbeite von W. Migula. Band ii., Algen. I. Teil. Gera, 1907.

Further Records of Flowering-Plants (Phanerogams) and Ferns from the Isle of May. By William Evans, F.R.S.E.

The following botanists have recorded their observations on the Flora of the Isle of May, at the mouth of the Firth of Forth :-

John Sadler ("Trans. Bot. Soc. Edin.," vol. xi. pp. 390$392,1873)$.

John Rattray (ibid., xvi. pp. 115-121, 1884).

William Evans (ibid., xxiii. pp. 348-351, 1908; and xxiv. pp. 91-93, 1910).

George West ("Proc. Roy. Soc. Edin.," xxx. pp. 173$177,1910)$.

With the exception of my own-which are concerned entirely with the Mosses and Hepatics-these papers deal more or less with the Phanerogams and Ferns. ${ }^{1}$ Sadler, who visited the island along with Professor J. H. Balfour

1 A few Fungi from the May have been recorded by Mr. A. B. Steele and myself ("Ann. Scot. Nat. Hist." 1908, p. 58, and 1910, p. 58). To these there falls to be added Crucibulum vulgare, Tul., which I found in Sept. 1910 growing on a piece of old wood in the south garden. 
and others in August 1871, recorded eighty-three of the former, and one of the latter, namely, Asplenium marinum. To that list Rattray added twenty, including a fern, Lastrea (sic) Felix-foemina. West mentions other eightamong them a third fern, Asplenium Ruta-murariaseen by him in August 1905.

The undernoted further additions to the list have at one time or another been collected by me on the island; they comprise twenty Phanerogams and two Ferns. Some of the Phanerogams flower early, which probably accounts for their absence from previous records. A number are garden weeds, a class from which a few more additions might doubtless have been made had one cared to look specially for them.

It would seem that the Flora of the island has undergone some changes in recent years. Several of the plants previously recorded-Mertenzia maritima, Lotus corniculatus, and Sedum acre, for instance-I am unable to find; while others stated to have been common are, in my experience, scarce and vice versâ. For instance, Mr. West speaks of Bellis perennis (the daisy) as "scarce near the houses"; this year, in June, the grassy banks by the roadside from the landing stairs to the lighthouse, and down by the harbour, etc., were literally white with daisies. On the other hand, Galium verum, referred to as common, I have had difficulty in finding; its congener, G. saxatile, however, is plentiful. Since the cropping of the enclosures (now in grass) was discontinued, a number of field weeds are quite likely to have disappeared. The introduction of a few plants of the Sea Buckthorn (Hippophae rhamnoides) to the engineer's garden this spring should, perhaps, be mentioned, so that its origin may be known in the event of the shrub becoming established on the island.

\section{List of ADDITIONS.}

Ranunculus Ficaria, L.--Fairly plentiful in the beginning of June 1910, and again this year, immediately to the north of the lighthouse.

Fumaria officinalis, L.-In garden south of the enginehouse, June 1910 and 1911.

Capsella Bursa-pastoris, Medic.-Common about the gardens and adjoining ground. 
Viola sylvetica, Fries (? Riviniana, Reichb.).-On 2nd June this year I observed about a dozen plants of what I have been accustomed to call Viola sylvatica in flower on a grassy bank close to the lighthouse. The lighthouse keepers say they first noticed it there two years ago.

Lyclenis dioica, I. (diurna, Sibth.).-A group of less than a dozen plants on steep bank on the south side of the loch, July 1910 and 1911.

Vicia lathyroides, L.-In some abundance in front of the lighthouse in beginning of June 1910, and on bank near the harbour, 2nd June 1911.

Apium graveolens, L.-Specimens collected on the May in 1879 are in my herbarium.

Chrysanthemum segetum, L.-A single plant in flower in a patch of oats, south garden, July 1911.

Anogallis arvensis, L.-Two or three plants in garden, July 1911.

Convolvulus arvensis, L.-In flower by side of path in south garden, July 1910, and again 7th July 1911. Has, I am told, been there for a number of years.

Veronica agrestis, L.-A common weed in the gardens, August 1910 and July 1911.

Lamium hybridum, Vill. (incisum, Willd.).--Several plants seen about the gardens in August 1910; common, .July 1911.

Eupleorbia Peplus, L.-A good many plants in south garden, July 1911.

Juncus Gerardi, Loisl.-In a moist spot close to the sea on the south-east of the island, July 1910; and at one higher up this year.

Koeleria cristata, Brit. auth. (? britannica, Domin).Common on the higher, rocky parts, June 1910 and 1911. ${ }^{1}$ Noted also in June 1899.

Dactylis glomerata, L.-Common about the gardens and grass enclosures.

Pow protensis, L.-At side of garden, etc., June 1911.

Festuca duriuscula, L.-At foot of wall round south garden, etc., June 1910 and 1911.

I Since these notes were put together, I have submitted specimens to Mr. G. C. Druce, and he says they are $K$. britannica, but not an extreme form.

TRANS. BOT, SOC. HDIN. vOL, XXIV. 
F. elatior, L.-Two or three plants on low ground south of harbour, July 1911.

Nardus stricta, L.-On 8th June this year my son drew my attention to this grass on a knoll above the harbour, and a week later I found it in abundance to the north of the lighthouse.

Lastrea dilatata, Presl--Among grass on low rock-ledges in several places in the southern half of the island, September 1910. A small form, such as one meets with on the hills.

Polypodium vulgare, L-A good-sized patch on steep bank, south of the loch, September 1910. It had been sadly spoiled by excursionists in the belief that it was the sea spleenwort.

The two species above recorded, and Aspleniwm marinum, which grows in several places on the cliffs and in the caves. are the only ferns I have seen on the island. 